\title{
The Obsession of Female Major Character in Divergent Novel
}

\author{
Ramis Rauf ${ }^{1}$, Fina Amalia Masri² \\ \{ramis.rauf01@gmail.com¹, finaamaliamasri@gmail.com²\}
}

Alumni Duta Bahasa Nasional 2013, Kendari ${ }^{1}$, Faculty of Cultural Sciences, Halu Oleo University, Kendari ${ }^{2}$

\begin{abstract}
This study is aimed to analyze Divergent novel by Veronica Roth in the case of the obsession of female major character. The problem in this study is analyzed by using Sigmund Freud's Psychoanalysis theory. The problem of this study is "how is the obsession of female major character in Divergent Novel By Veronica Roth?". The research method of this study is qualitative descriptive analysis. The source of data in this study is Divergent novel which published in 2011 in America. The data collected through reading comprehension, notes and selecting by the relevant information to get a complete analysis about the obsession of female major character. The result of analysis found that the obsession of female major character in Divergent novel by Veronica Roth, namely Jeanine Matthews is trying to overthrow the government Abnegation factions by the following steps: 1) she wrote an article or report to make people believe that Beatrice's father and all the other Abnegation leaders are corrupt and awful, 2) she worked with Will's sister to develop a longer-lasting serum for the simulations because she wants to control them (Dauntless factions). She needs to control large groups of people to stay secure, so she developed a way to do it with serums and transmitters. Divergence is just another problem for her to solve, and that is what makes her so terrifying because she is smart enough to solve anything, even the problem of Divergent existence.
\end{abstract}

Keywords: obsession, female major character, divergent.

\section{Introduction}

Literature is a creative work of a thought process to convey ideas, experiences, and systems thinking or theory. Abrams (Norton, Rushton, 1957) expressed that "literature as a raw expression of what he/she had witnessed, experienced and felt by people about aspects of life". Thus, literary works will be revealed through human appreciation of the deepest in the world.

Literature is creating in tune with the dynamics of society and culture. Growth and development of literature is very dependent on the social system and culture of the people. Literary works always used to express the collective human personality through the merging of individual literary imagination with society's obsession [1]. It is reinforced by the Hamalian's statement [2] that:

Literature is a product of a society, reflecting the community. The society's obsession

becomes an obsession author, who became members of the community to be able to study

the literature study is to learn the aspirations of the people of that society, its cultural level, tastes, outlook on life, etc.

Literary works not only as modifying of imagination, but also as a mirror of society. In this case Hamalian (1970) says that, "the literary works records of suffering and hope of a society, 
so that the nature and problems of an era can be read in the literature". This social dimension is emphasized by Thrall [4], who said that "literature is a direct reflection of various aspects of social structure."

In its development, literary works have many forms. The major forms of literature are novel, poem, drama, short story, and novella. These main forms of literature can be written in various genres. Genre is a category characterized by similarities in form, style, or subject matter. The classic major genres of literature: Comedy, Romance, Tragedy, and Satire [1]. The major literary works take factual themes that reflected by the real-life at the time the works are produced. These forms of literary works represent two dimensions: the idea and the works itself.

One form of literary works is novel. It uses the words to present the works. According to Abrams [5], "...its (novel) magnitude permits a great variety of characters, greater complication of plot..." The ideas flow naturally word by word. It is stated by Abrams as "great variety of writings". Thus, the reader can read the situation in the works in detail. They can also feel the situation by their imagination. The novel is known in Indonesia after the writers are turning to English books. So, these are the reasons why the writer chooses Divergent novel by Veronica Roth as the object of the study.

Divergent is the debut novel of American novelist Veronica Roth, published by Harper Collins Children's Books in 2011 with 226 pages. The novel is the first of the Divergent trilogy, a series of young-adult dystopian novels set in the Divergent Universe. It presents how to interpret the story of life experiences, such as joy and sorrow, affection, truth, lust and all of the things that happen in human life experiences, especially obsession or someone wishes are realized by shortcuts with high risk [6].

Based on the description, the writer formulates the research question: How is the obsession of female major character in Divergent Novel By Veronica Roth?. It will be analyzed by using Sigmund Freud's psychoanalysis theory. It includes all side of literary work both intrinsic and extrinsic as a structural analysis. Psychoanalysis theory is relevant to the object of the study because obsession is part of psychological. It draws by the personality structures and mental protection. Personality structures are composing of three elements. These three elements of personality are known as the id, ego, and the superego that work together to create complex human behaviors. Meanwhile, mental protections are rationalization, projection, sublimation, reaction formation, displacement, denial, and regression.

\section{Method}

The type of research in this study is qualitative descriptive analysis. It means that the importance of this study uses the resources of materials from libraries because every purpose of the study is to find, develop, or test the truth of an empirical knowledge based on data and fact as a basis to act. The ability to do qualitative descriptive analysis begins with an understanding of how libraries organize their collections and with a knowledge of basic bibliographic and reference materials [7].

According to Sukmadinata [8] basic of qualitative descriptive analysis is constructivism, assume that reality is plural dimensional, interactive and an exchange of social experiences interpreted by an individual. Research is guided by the qualitative paradigm is defined:

"an inquiry process of understanding a social or human problem based on building

a complex, holistic power, formed with words, reporting detailed views of

informants, and conducted in a natural setting" [9]. 
Based on the description of the qualitative method above, this research applied qualitative descriptive analysis to analyze the objective of this study, which reveals the obsession of female major character in Veronica Roth's Divergent. In doing this study, the writer uses two sources of data, namely primary and secondary data sources. The primary data source is the novel itself, Divergent by Roth Veronica. Divergent is the first sequel of the trilogy of Divergent. Divergent is published by Harper Collins Children's Books in 2011 with 226 pages. The secondary data are taking from other sources which are related to the primary data such as the biography of the author, and using the theory of psychoanalysis by Sigmund Freud.

In collecting data, the writer uses the following steps based on Sarah Griffith [10], as follows:

1. Firstly, the writer reads and comprehends the primary and secondary data source;

2. Secondly, the writer notes down of important information in both source;

3. Thirdly, the writer selects them by accepting the relevant information with the problem and rejecting the irrelevant information that does not support the topic of the study. This process helped the writer to understand the problem of this study to get a complete analysis

In analyzing the data, the writer uses the following steps, as follows:

1. Understanding the theory of psychoanalysis by Sigmund Freud;

2. Finding the material of psychoanalysis to connect with the object of the study;

3. Classifying the novel of Divergent as a literary work, especially structural analysis. It consists of two categories, such as intrinsic and extrinsic elements. The intrinsic element of a literary work includes elements which establish a literary work inside. The elements are setting, character and characterization, and conflict [11]. For that reason, the analysis of any kind of literary work needs a good knowledge of literary elements. Extrinsic element refers to social condition in a society and psychological condition.

\section{Theoretical Frameworks}

Psychoanalysis is one way to analyze feelings, behaviors, thoughts, consciousness, and unconsciousness that guiding an individual to adapt to the social environment and also the physical environment. To develop a personality, we should try to unity and maintain harmony among all of the elements of personality [12]. He developed some of the most influential theories in modern psychology and psychoanalysis.

A developmental psychologist may order what makes us progress as individuals. One obvious insight is that the life drive pushes personal progress. Its need for harmony and balance within the nervous system creates an incentive to do the things we deem acceptable as a society. It appears that personality development was driven by the desire for immediate resolution of the problems we face as human beings [13]. Even memory is often noticeably affected, as we have seen. The complex must, therefore, be a psychic factor which in terms of energy, possesses a value that sometimes exceeds our conscious intentions, otherwise such disruptions of the conscious order would not be possible at all. An active complex puts us momentarily under a state of duress of compulsive thinking and acting.

In psychoanalytic theory, the mind protects itself from threats by using defense mechanisms such as rationalization, projection, sublimation, reaction formation, displacement, denial, and regression. According to Sigmund Freud's Psychoanalytic Theory of Personality, personality is composed of three elements. These three elements of personality are known as the $i d$, ego, and the superego that work together to create complex human behaviors. This 
study just describes the ego as the main factor to create an obsession. Ego is the component of personality that is responsible for dealing with reality.

According to Freud [14], Ego develops from the id and ensures that the impulses of the id can be expressed in a manner acceptable in the real world. Ego functions in both the conscious and unconscious mind. It operates based on the reality principle, which strives to satisfy the id's desires in realistic and socially appropriate ways. Freudian conceptualization, ego refers to a physic structure which mediates between society (superego) and instinct drives (id).

According to Freud [14], the mind is best conceptualized in two distinct components; those are the consciousness and the unconsciousness. The consciousness is perceived by our ego that includes all of concerning self and the environment of the person's life, inner, and outer. As a part of consciousness, ego is playing an important role to determine perceptions, feelings, thoughts, and memories to maintain the integrity of the personality and give people a sense of continuity and identity. The consciousness is being often weak, given to submit the argues and desires of the body and waking mind.

Freud [15] states that the ego is responsible for repressing unconscious thoughts. Things that are too disturbing to face immediately are pushed out of the individual. This psychological pressure creates a continuous battle between the ego and unconscious portions of the psyche. Each component is responsible for one of the various functions the mind executes.

Meanwhile, an obsession is the inability of a person to stop thinking about a particular topic or feeling a certain emotion without a high amount of anxiety. When obsessed, an individual continues the obsession to avoid the consequent anxiety. In the case of obsessivecompulsive disorder (OCD), the individual may have only the obsessions, compulsions or both [16].

Obsessive-compulsive disorder (OCD) is an anxiety disorder in which people have unwanted and repeated thoughts, feelings, ideas, sensations (obsessions), or behaviors that make them feel driven to do something (compulsions). Often the person carries out the behaviors to get rid of the obsessive thoughts, but this only provides temporary relief. Not performing the obsessive rituals can cause great anxiety. A person's level of OCD can be anywhere from mild to severe, but if severe and left untreated, it can destroy a person's capacity to function at work, at school or even to lead a comfortable existence in the home [17].

According to Brown \& Lynn (1976), obsession is a fixed idea that occupies one's mind. Sometimes obsession can be an aspiration for us to chase what we in life but sometimes we are obsessed with something which is not good. Rachman and Hodgson (in Rachman, 1998: 455) propose that obsessions are caused by catastrophic misinterpretations of the significance of one's intrusive thoughts.

The central feature of obsessive thinking is compulsive and repetitive mental preoccupation with images, ideas or words that the individual finds highly disturbing. Typically the client experiences intrusive distressing thoughts that interfere with daily living and attempts to control these by further thoughts that seek to neutralize initial distressing ones [10].

Relative to obsessive-compulsive disorder, obsessive thinking has received little attention by academics or practitioners, perhaps reflecting the difficulties of accessing and controllingneutralizing strategies that are covert [19]. Nevertheless, it can be described as an important variant of the condition, differentiated by the absence of ritualized behavior patterns [20]. It has been suggested that the content of obsessive thinking is commonly drawn from primitive sexuality and aggression. The object of aggression is often apparent, spouse, or child [16]. 


\section{Analyses and Discussion}

This study aims to analyze the obsession of female major character, namely Jeanine Matthews. Her obsession is to become the leader for all factions. Obsession is a feeling or emotions that influence thinking. So, it causes distress and anxiety. Freud [13] stated that the features of obsession are sensations, compulsions, and ego. All the features of obsessions are presented as the way to create Jean's obsession to become a leader.

\subsection{Compulsion}

According to Freud [21], compulsions are defined as performing an act persistently and repetitively without it necessarily leading to an actual reward or pleasure. Compulsions could be an attempt to make obsessions go away. It needs to reduce apprehension caused by internal feelings a person wants to abstain or control. It can be proved by the following quotation:

"As to the reason for your presence here... a quality of my faction is curiosity," she says, "and while perusing your records, I saw that there was another error with another one of your simulations. Again, it failed to be recorded. Did you know that?" [6].

The quotation described as one kind feature of obsession. It is called as compulsions. It showed the conversation between Jeanine and Tris. Jean feels that there was something wrong with Tris' result of the aptitude test. It makes her curiosity, but she wants to abstain or control her compulsion. Jean still does not believe why the aptitude test failed to be recorded Tris' simulation. It makes distress and anxiety for Jeanine. 


\subsection{Sensation}

Sensation based on Freud (in Cooper, 2000) is a physical feeling or perception from something that comes into contact. It can be proved by the following quotation below:

"Jeanine gives speeches about how corrupt Abnegation is all the time, almost every day. " [6].

The quotation described that Jeanine makes a sensation through her speech in front of her faction (Erudite) to inform them about the Abnegation's leaders is a corruptor. The report label Tris' family as a corruptor, power-hungry, and moralizing dictators. She also says how corrupt Abnegation's leader is all the time.

\subsection{Ego}

Ego is the main factor to create an obsession. Ego is the component of personality that is responsible for dealing with reality [22]. It can be shown by Jean's report. The report showed that carry subtle threats and hint at revolution. It can be proved by the following quotation below.

"Improved, and working toward a world in which people will live in wealth, comfort, and prosperity," Jeanine says. [6]

The quotation showed that Jean's report. It described that if Jeanine became a leader she guaranteed they live in wealth, comfort, and prosperity. It showed as Jean's ego.

\subsection{Jean's Strategy to Get Her Obsession}

The obsession of Jean is becoming a leader. She has two strategies to get her obsession, those are:

\subsubsection{Black Campaign}

The first strategy was sending a report to all factions to overthrow the leader of Abnegation. It can be seen by the following quotation:

"Not even after your faction's leaders decided to join in a plot to overthrow the government?" [6].

The quotation described that Jean tried to overthrow the Abnegation government. It showed a black campaign. Black campaign is false information and material that purports to be from a source on one side of a conflict, but is typically used from the opposing side. It is typically used to vilify, embarrass or misrepresent the enemy. Sometimes the source is concealed or credited to a false authority and spreads lies, fabrications, and deceptions. Jean tried to influence the other factions by a report. It can be proved by the following quotation:

"His eyes scan the paper again."

"However, perhaps the answer lies not in a morally bereft man, but the corrupted ideals of an entire faction. Perhaps the answer is that we have entrusted our city to a group of proselytizing tyrants who do not know how to lead us out of poverty and into prosperity." $[6]$.

The quotation showed the content of Jeanine's report about the weakness of Abnegation's government leaders. She said that all factions has entrusted for the leaders of Abnegation because they do not know how to lead all the factions out of poverty and into prosperity. 


\subsubsection{Developing Serum and Aptitude Test}

After she wrote a report about the failure of Abnegation's government, she tries to develop a longer-lasting serum for the simulations and aptitude tests. It can be seen by the following quotation below.

"Before she was a leader she worked with my sister. They were trying to develop a longerlasting serum for the simulations," [6].

The quotation described that Jeanine worked with Will's sister to develop a serum for the simulation of fear. It showed that she wants to control all Dauntless. She wants everyone to be pliable and easy to control their activities, feelings, and thinking. She did not have an army, so she found one in Dauntless. She knew that she would need to control large groups of people to stay secure, so she developed a way to do it with serums and transmitters. It is the way to collect the power to overthrow Abnegation's leader. Then, she tries to make a deal with dauntless leader that new improvement of government. It can be seen by the following quotation below.

"Weak-willed is mind-controlling an army because it's too hard for you to train one yourself." "I am not a fool," says Jeanine. "A faction of intellectuals is no army. We are tired of being dominated by a bunch of self-righteous idiots who reject wealth and advancement, but we couldn't do this on our own. And your Dauntless leaders were all too happy to oblige me if I guaranteed them a place in our new, improved government" [6].

The quotation showed that Jeanine tries to convince that if she becomes a leader, she guaranteed a place in their new improvement of government. So she worked together with Will's sister to develop serum to control them. Will's sister name is Cara. Cara and Will from Erudite faction. It can be seen through the below:

“Statistically speaking," the Erudite boy next to me-his name is Will [6].

The quotation showed that Will comes from Erudite. They do not like stupid people, but he decided to leave his faction and he chooses Dauntless as his new faction. It can be seen by the following quotation:

Will laughs. "No, they're not. They're arrogant and dull, and that's why I left them, but they aren't revolutionaries. They just want more say, that's all, and they resent Abnegation for refusing to listen to them" [6]

The quotation described that Will left his faction because all of the members of Erudite was so arrogant and dull. On the other hand, Jean and Will's sister developed an aptitude test to find people who Divergent are. It can be seen by the following quotation below.

"The aptitude test is by far my greatest achievement as a scientist." [6].

The quotation showed the greatest achievement from Jeanine. This test was conducted by all members of factions. It is one of her primary goals. Her primary goal is to neutralize the threat posed by the Divergent's ability to crack simulations. It purposes to look for a Divergent 
because she believes that Divergent is extreme danger and also become a problem for her. So that's why she develops a serum and aptitude test to support her obsession to become a leader.

Based on the description above, the writer concluded that the obsession of female major character, namely Jeanine Matthews is to become the leader for all factions. She wants to control all Dauntless. She wants everyone to be pliable and easy to control. She is more machine than maniac. She sees problems and forms solutions based on the data she collects. Abnegation stood in the way of her desire for power, so she found a way to eliminate it. But she didn't have an army, so she found one in Dauntless. She knew that she would need to control large groups of people to stay secure, so she developed a way to do it with serums and transmitters. Divergence is just another problem for her to solve, and that is what makes her so terrifying because she is smart enough to solve anything, even the problem of Divergent existence. Her obsession is influenced by the three features of obsession; those are sensations, compulsions, and ego. Sensation is proven by the report of Abnegation's leader. Compulsion is proven by Jeanine's curiosity to Tris' result of aptitude test. And ego is proven by Jean's hope to work together with Dauntless' leader.

This obsession is negative things because it is called a black campaign for the other faction. Black campaign is false information and material that purports to be from a source on one side of a conflict, but is typically used from the opposing side. It is typically used to vilify, embarrass or misrepresent the enemy. Sometimes the source is concealed or credited to a false authority and spreads lies, fabrications, and deceptions.

\section{Conclusion}

This study draws a conclusion based on the description previous chapter that the obsession of female major character in Divergent novel by Veronica Roth, namely Jeanine Matthews is trying to overthrow the government Abnegation factions by the following steps: 1) she wrote an article or report to make people believe that Beatrice's father and all the other Abnegation leaders are corrupt and awful. This report is a part of her strategy to make sure that they choose Abnegation as a government to lead all factions is a mistake. She said that all factions has entrusted for the leaders of Abnegation because they do not know how to lead all the factions out of poverty and into prosperity, and 2) she worked with Will's sister to develop a longer-lasting serum for the simulations because she wants to control them (Dauntless factions). She needs to control large groups of people to stay secure, so she developed a way to do it with serums and transmitters. Divergence is just another problem for her to solve, and that is what makes her so terrifying because she is smart enough to solve anything, even the problem of Divergent existence. Her obsession is influenced by the three features of obsession, those are sensations, compulsions, and ego. Sensation is proven by the report of Abnegation's leader. Compulsion is proven by Jeanine's curiosity to Tris' result of aptitude test. And ego is proven by Jean's hope to work together with Dauntless' leader. This obsession is negative things because it is called a black campaign for the other faction. Black campaign is false information and material that purports to be from a source on one side of a conflict, but is typically used from the opposing side. It is typically used to vilify, embarrass or misrepresent the enemy. Sometimes the source is concealed or credited to a false authority and spreads lies, fabrications, and deceptions. 


\section{References}

[1] D. S. Norton, P. Rushton, and M. H. Abrams, "A Glossary of Literary Terms," Coll. Compos. Commun., 1957.

[2] V. Oshagan, "Literature of the Armenian Diaspora," World Lit. Today, 1986.

[3] L. Hamalian, "Waiting for Godard," J. Pop. Cult., 1970.

[4] J. M. Steadman, W. F. Thrall, and A. Hibbard, "Useful HandbookA Handbook to Literature, with an Outline of Literary History, English and American," South Atl. Bull., 1936.

[5] F. S. Giles, L. Hamalian, and J. V. Hatch, "The Roots of African American Drama: An Anthology of Early Plays, 1858-1938," MELUS, 1991.

[6] V. Roth, "Divergent," Harper Collins, 2011.

[7] M. E. Schirber, W. J. Goode, and P. K. Hatt, "Methods in Social Research," Am. Cathol. Social. Rev., 1953

[8] Y. Yusmawati and J. Lubis, "The Implementation of Curriculum by Using Motion PatternBased Learning Media for Pre-school Children,” JPUD - J. Pendidik. Usia Dini, 2019.

[9] S. S. Magnan and J. W. Creswell, "Research Design: Qualitative and Quantitative Approaches," Mod. Lang. J., 1997.

[10] S. Cooper, "Obsessional thinking - A defense against loss," Br. J. Psychother., 2000.

[11] M. Abduh, "PENGEMBANGAN MEDIA PEMBELAJARAN TEMATIK- INTEGRATIF BERBASIS SOSIOKULTURAL BAGI SISWA KELAS IV SEKOLAH DASAR," Profesi Pendidik. Dasar, 2016.

[12] S. Freud, "An Outline of Psycho-Analysis," in The Standard Edition of the Complete Psychological Works of Sigmund Freud, Volume XXIII (1937-1939): Moses and Monotheism, An Outline of Psycho-Analysis and Other Works, 1938.

[13] G. S. Hall, S. Freud, and J. Riviere, "Introductory Lectures on Psychoanalysis," Am. J. Psychol., 1923.

[14] K. M. Bowman, S. Freud, and J. Riviere, "The Ego and the Id," Am. J. Psychol., 1928.

[15] L. R. WOLBERG, "Freudian Psychoanalytic Theory," in Perspectives in Abnormal Behavior, 1974.

[16] H. J. Eysenck and S. Rachman, The causes and cures of neurosis: An introduction to modern behavior therapy based on learning theory and the principles of conditioning. 2013.

[17] S. Freud, "Notes upon a case of obsessional neurosis ('The rat-man')," Stand. Ed., 1909.

[18] L. A. Brown and R. W. Lynn, "Oxford Advanced Leamer s Dictionary of Current English," RELC Journal. 1976.

[19] C. Mace, "Book review: What Works for Whom? A Critical Review of Psychotherapy Research (2nd eds).," The British Journal of Psychiatry. 2005.

[20] R. J. Hodgson and S. Rachman, "Obsessional-compulsive complaints," Behav. Res. Ther., 1977.

[21] W. J. Jenkins, The interpretation of dreams. 2017.

[22] M. GENESI, "Sigmund Freud (1856-1939).," Minerva Med., 1956. 